\title{
PEMBELAJARAN BERBASIS MASALAH BERPENDEKATAN SOCIOSCIENTIFIC ISSUE TERHADAP SIKAP PEDULI LINGKUNGAN DAN HASIL BELAJAR SISWA
}

\author{
Muhamad Nur Khozin ${ }^{1}$, Atik Rahmawati ${ }^{2}$, Teguh Wibowo ${ }^{3}$ \\ ${ }^{1,2,3}$ Universitas Islam Negeri Walisongo Semarang
}

\begin{abstract}
Tujuan dari penelitian ini adalah untuk mengetahui efektivitas model pembelajaran berbasis masalah berpendekatan socioscientific issue terhadap sikap peduli lingkungan dan hasil belajar siswa pada materi minyak bumi di MAN 2 Rembang. Penelitian ini menggunakan metode eksperimen dan menggunakan desain penelitian noneqivalent control group design. Teknik pengumpulan sampel dengan menggunakan teknik cluster random sampling, didapatkan dua kelas sampel yaitu kelas eksperimen (XI MIPA 1) dan kelas kontrol (XI MIPA 2). Data penelitian dianalisis dengan menggunakan uji perbedaan rata-rata, uji efektivitas variabel, dan uji korelasi antar variabel. Hasil penelitian diperoleh peningkatan rata-rata sikap peduli lingkungan dan hasil belajar kelas ekperimen 43,04 dan 44,74 sedangkan kelas kontrol 26,23 dan 24,38. Uji efektivitas variabel menghasilkan nilai Asymp. Sig. (2-tailed) sebesar $0,000<$ nilai probabilitas 0,05 untuk sikap peduli lingkungan dan nilai Asymp. Sig. (2-tailed) sebesar 0,000 < nilai probabilitas 0,05 untuk hasil belajar. Uji korelasi antar variabel menghasilkan nilai $\mathrm{rxy}=0,617$ dan dinyatakan signifikan dengan korelasi cukup kuat. Berdasarkan hasil penelitian dapat disimpulkan bahwa penerapan model pembelajaran berbasis masalah berpendekatan socioscientific issue efektif digunakan pada pembelajaran untuk meningkatkan sikap peduli lingkungan dan hasil belajar siswa pada materi minyak bumi di MAN 2 Rembang.
\end{abstract}

Kata kunci: pembelajaran berbasis masalah, sikap peduli lingkungan, hasil belajar

\begin{abstract}
The purpose of this research is to find out the effectiveness of problem-based learning models with socioscientific issue approach to environmental care attitudes and student learning outcomes in petroleum material at MAN 2 Rembang. This study uses an experimental method and uses a non-eqivalent control group design research design. Sample collection techniques using cluster random sampling techniques, obtained two sample classes, namely the experimental class (XI MIPA 1) and the control class (XI MIPA 2). The research data were analyzed using the average difference test, the variable effectiveness test, and the correlation test between variables. The results obtained by an average increase in environmental care attitudes and learning outcomes of experimental class 43.04 and 44.74 while the control classes 26.23 and 24.38. Test the effectiveness of variables produce Asymp values. Sig. (2-tailed) of 0,000 <probability value of 0.05 for environmental care attitudes and Asymp values. Sig. (2-tailed) of 0,000 <probability value of 0.05 for learning outcomes. Correlation test between variables produces a value of
\end{abstract}

Universitas Islam Negeri Walisongo

Email: muhamadnurkhozin96@gmail.com
(C)2020 Universitas Islam Negeri Walisongo

ISSN: 2088-7868, e-ISSN 2502-5708 
rxy $=0.617$ and is declared significant with a strong enough correlation. Based on the results of the study it can be concluded that the application of problem-based learning models with socioscientific issue approach is effectively used in learning to improve environmental attitudes and student learning outcomes in petroleum material at MAN 2 Rembang.

Kata kunci: problem based learning, environmental care attitude, learning achievement

\section{PENDAHULUAN}

Kurikulum yang mengutamakan pemahaman, keterampilan, dan pendidikan karakter pada siswa adalah kurikulum 2013. Siswa diharuskan untuk berperan aktif dalam pembelajaran dan memiliki karakter yang baik salah satunya adalah sikap peduli terhadap lingkungan. Sikap peduli lingkungan dapat diartikan sebagai sikap untuk dapat mencegah kerusakan alam di lingkungan sekitar dan mengembangkan upaya untuk memperbaiki kerusakan alam yang telah terjadi sehingga keragaman lingkungan dapat dinikmati tanpa merusak kelestarian lingkungan, serta menjaga keragama hayati (Purwanti, 2017). Dewasa ini, masalah lingkungan menjadi persoalan yang sangat tidak biasa di tengah kehidupan masyarakat. Masyarakat kurang mempedulikan limbah yang dihasilkan mereka yang telah mencemari lingkungan. Hal ini dibuktikan dengan keberadaan sampah yang terdapat di sungai, laut, dan naiknya temperatur bumi.

Sikap sadar terhadap permasalahan lingkungan perlu ditanamkan sejak dini supaya dapat membentuk karakter anak yang peka terhadap lingkungan. Sikap peduli lingkungan dapat ditanamkan ketika menempuh pendidikan di sekolah yang bisa dikorelasikan dengan materi pembelajaran (Lestari, 2018). Satu dari beberapa materi pelajaran kimia untuk SMA kelas XI semester gasal yang dapat dikorelasikan dengan keadaan lingkungan sekitar adalah minyak bumi. Pada materi minyak bumi membahas tentang proses pembentukan, komposisi, pengolahan, pemisahan, dan manfaat minyak bumi. Minyak bumi sangat bermanfaat bagi kehidupan manusia, masyarakat menggunakan minyak bumi untuk bahan bakar kendaraan bermotor, bahan bakar kompor, pembuatan jalan dan lain-lain. Disisi lain pemakaian minyak bumi yang berlebihan akan berdampak pada pencemaran lingkungan, seperti pencemaran udara.

Pada kondisi saat ini siswa harus dibekali sikap peduli terhadap lingkungan, karena sebagai generasi penerus bangsa setiap orang diharaplan dapat merawat lingkungannya. Siswa yang yang memiliki sikap kurang peka terhadap lingkungan akan memberikan dampak yang buruk pada lingkungan disekitar (Susanti, Masriani, \& Hadi, 2017). 
Semakin banyak limbah yang dihasilkan akan semakin luas kerusakan lingkungan. Sehingga perlu adanya pembelajaran yang dapat menstimulus kepekaan siswa terhadap lingkungan sekitar dan diharapkan dapat mengaplikasikan dalam kehidupan sehari-hari serta dapat memberikan solusi yang tepat terhadap permasalahan lingkungan yang terjadi (Sofiana \& Wibowo, 2019).

Hasil wawancara dengan guru kimia di MAN 2 Rembang menjelaskan bahwa pelaksanaan pembelajaran di kelas guru lebih sering menggunakan Lembar Kerja Siswa (LKS) dan jarang melakukan pembelajaran yang berpusat pada siswa. Penyampaian materi dengan menggunakan LKS dirasa lebih tepat. Akan tetapi materi yang terdapat pada LKS kurang lengkap, sehingga perlu adanya materi tambahan yang diberikan oleh guru. Disisi lain ketika guru menggunakan pembelajaran yang berpusat pada siswa, pembelajaran tersebut dianggap kurang efektif dikarenakan terikat dengan waktu yang sedikit untuk dapat menyampaikan materi yang banyak.

Pembelajaran yang dilakukan dengan mengaitkan keadaan lingkungan di sekitar tempat tinggal siswa akan menjadikan pembelajaran lebih bermakna (Zuchdi, Ghufron, Syamsi, \& Masruri, 2014). Pembelajaran berbasis lingkungan memerlukan aspek kontekstualitas, karena ruang lingkup permasalahan lingkungan bekaitan erat dengan kegiatan kehidupan sehari-hari yang tidak hanya melibatkan pengetahuan tentang lingkungan tetapi juga memerlukan sikap yang positif dan upaya menyelesaikan masalahan lingkungan. Siswa dapat menyelesaikan masalah dengan berbekal pengetahuan dan pemahaman konsep pembelajaran yang mendalam daripada hanya memahami materi pelajaran.

Pemahaman konsep yang kurang tepat dapat berakibat pada hasil belajar kimia siswa yang kurang memuaskan. Hasil belajar siswa yang tidak memenuhi KKM disebabkan pembelajaran yang kurang berkesan sehingga membuat siswa kurang antusias untuk mengikuti pembelajaran. Berdasarkan hasil belajar yang tidak memenuhi KKM dapat dikatakan siswa tidak memahami materi yang disampaikan oleh guru.

Model pembelajaran yang kurang tepat dapat memberikan dampak tersebut, maka diperlukan model pembelajaran yang dapat menarik siswa untuk antusias dalam pembelajaran. Menurut Agustina, Ashadi, \& Mulyani (2017) bahwa pembelajaran berbasis masalah (PBM) merupakan satu dari sekian banyak model pembelajaran yang dapat merangsang pemikiran siswa sehingga dapat berperan aktif dalam pembelajaran. Model 
pembelajaran yang tepat dapat memberikan dampak yang positif bagi siswa. Materi akan mudah diingat apabila siswa merasa puas atau senang dalam kegiatan pembelajaran (Subandi, Joharmawan, \& Santoso, 2017). Esensi pembelajaran berbasis masalah melibatkan situasi-situasi kehidupan nyata di lingkungan sekitar yang berfungsi sebagai landasan bagi identifikasi masalah dan penyelidikan siswa. Langkah selanjutnya siswa melakukan kolaborasi untuk menemukan solusi nyata yang digali dari berbagai literatur dan melibatkan banyak subyek.

Pembelajaran berbasis masalah memberikan kesempatan kepada siswa dalam berpikir untuk menyelesaikan masalah yang didapatkan dan mengkomunikasikan berbagai informasi kepada sesama siswa dengan menggunakan alat penunjang pembelajaran seperti fasilitas internet atau buku cetak sebagai referensi yang dapat mendukung menyelesaian masalah (Sulaeha, Danial, \& Wijaya, 2016). Siswa diharapkan dapat mengkorelasikan materi pelajaran dengan fakta yang ada di lingkungan sekitar. Model PBM sangat cocok untuk menyampaikan materi yang menyangkut pada permasalahan lingkungan yang mana penyelesaian masalahnya dapat menggunakan pendekatan Socioscientific Issue (SSI).

SSI merupakan strategi pembelajaran yang menyajikan materi sains dalam konteks isu-isu sosial dengan melibatkan komponen moral atau etika (Callahan, 2009). SSI memiliki konten isu permasalahan lingkungan yang berkembang di masyarakat secara konsep maupun prosedur yang berhubungan dengan sains dan dipengaruhi oleh aspek sosial, budaya, ekonomi, dan politik (Tal, Kali, Magid, \& Madhok, 2011). Pembelajaran berbasis SSI menjadi cabang dari ilmu pengetahuan, teknologi dan masyarakat. Model pembelajaran ini memiliki pendekatan berbasis masalah untuk pembelajaran ilmu pengetahuan yang memiliki konteks sosial yang dapat disajikan dengan pandangan autentik kepada siswa tentang hubungan ilmu pengetahuan ilmu pengetahuan dan dunia nyata (Zeidler, Sadler, Simmons, \& Howes, 2005).

\section{METODE PENELITIAN}

Penelitian ini dilaksanakan di MAN 2 Rembang pada kelas XI MIPA Semester Gasal Tahun Pelajaran 2019/2020. Jenis penelitian yang digunakan yaitu penelitian eksperimen dengan desain nonequivalent control group design. Teknik pengambilan sampel secara cluster random sampling karena sampel berdistribusi normal dan homogen 
(Sugiyono, 2012). Sampel yang digunakan sebanyak 2 dari 5 kelas yaitu kelas XI MIPA 1 sebagai kelas eksperimen dengan diberikan perlakuan pembelajaran dengan menggunakan model pembelajaran berbasis masalah dan kelas XI MIPA 2 sebagai kelas kontrol dengan perlakuan pembelajaran menggunakan model pembelajaran konvensional.

Pada penelitian ini terdapat dua variabel, model pembelajaran berbasis masalah berpendekatan SSI adalah variabel bebas, sedangkan hasil belajar dan sikap peduli lingkungan siswa pada materi minyak bumi. Metode pengumpulan data menggunakan soal tes (hasil belajar) multiple choice, angket (sikap peduli lingkungan), observasi dan dokumentasi. Data hasil penelitian dianalisis secara kuantitatif. Instrumen pengumpulan data dengan tes terdiri atas 32 item soal dan instrumen non tes terdiri atas 31 item pernyataan. Pengujian instrumen dilakukan untuk mendapatkan data yang tepat dengan melaksanakan pretest dan posttest. Teknik analisis data yang digunakan adalah uji perbedaan rata-rata dengan menggunakan nilai pretest dan posttest soal dan angket, uji efektivitas variabel dengan Mann Whittney, dan uji korelasi antar variabel menggunakan nilai posttest.

\section{HASIL DAN PEMBAHASAN}

Penelitian ini menghasilkan data berupa data hasil belajar aspek kognitif, sikap, dan keterampilan berpikir sains. Tes pilihan ganda digunakan untuk mengukur tingkat pengetahuan siswa terhadap pembelajaran. Lembar observasi digunakan untuk mencari nilai pengukuran ranah sikap dan keterampilan. Keterampilan proses sains diukur dengan menggunakan tes berupa soal uraian dan lembar observasi. Penelitian tersebut menghasilkan data penelitian yang diperoleh dari dua sampel yang berbeda dan merupakan bagian dari populasi kelas XI MIPA MAN 2 Rembang. Kelas XI MIPA 1 dijadikan sampel kelas eksperimen yang terdiri dari 36 siswa. Kelas XI MIPA 2 dijadikan sampel kelas kontrol yang terdiri dari 33 siswa. Perlakuan pembelajaran biasa yaitu dengan metode ceramah dan diskusi diberikan kepada kelas kontrol sedangkan perlakuan model pembelajaran berbasis masalah dengan pendekatan SSI yang terdiri dari 5 sintaks yaitu: menyajikan masalah, mengorganisasi langkah pemecahan masalah, investivigasi masalah, pameran hasil karya, dan evaluasi hasil pemecahan masalah yang diberikan kepada kelas eksperimen.

Pelaksanaan pembelajaran berbasis masalah diterapkan pada kelompok belajar 
siswa. Lembar Kerja Siswa (LKS) berbasis SSI yang berisi masalah diberikan kepada setiap kelompok belajar. LKS SSI bertujuan untuk menunjang kegiatan pembelajaran

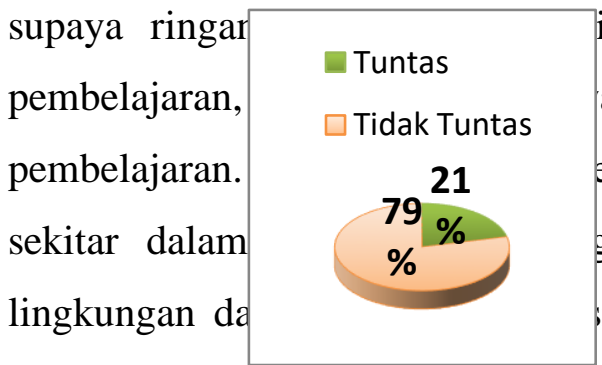
ikan tujuan pembelajaran, masalah dalam materi a, latihan soal, tugas mandiri, analisis dan evaluasi erikan berikatan dengan permasalahan lingkungan gsang siswa untuk mengembangkan sikap peduli il belajar siswa. Pengerjaan LKS SSI harus secara bersamaan dengan alur pembelajaran supaya kegiatan pembelajaran menjadi lebih tertata dan dapat meningkatkan kerjasama dan tanggung jawab siswa dalam memilih konsep penyelesaian masalah pada materi pembelajaran.

Penelitian yang dilakukan menghasil data berupa angka (kuantitatif) yang dapat digunakan uji hipotesis. Data yang diperoleh berasal dari pengukuran tes kognitif dan rekapitulasi angka respon sikap peduli lingkungan siswa terhadap penggunaan pembelajaran berbasis masalah berpendekatan SSI. Namun dalam penelitian ini hasil belajar hanya diukur pada ranah kognitif saja. Hal ini dengan alasan menjadi titik fokus dalam pengukuran. Berdasarkan analisis didapatkan bahwa kelas eksperimen memiliki rata-rata hasil belajar lebih besar daripada rata-rata hasil belajar siswa kelas kontrol.

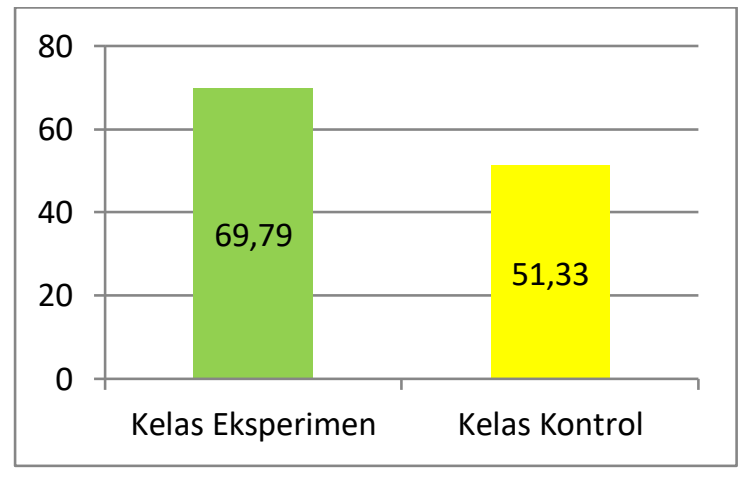

Gambar 1 Grafik Besaran Hasil Belajar

MAN 2 Rembang menentukan besaran KKM pada mata pelajaran kimia adalah 75 . Diketahui bahwa kelas eksperimen memiliki rata-rata hasil belajar (kognitif) siswa lebih besar daripada rata-rata hasil belajar (kognitif) pada kelas kontrol. Pada kelas eksperimen hanya 16 siswa yang tuntas dari jumlah keseluruhan 36 siswa. Sementara 20 siswa lainnya tidak tuntas. Pada kelas kontrol hanya 7 siswa yang tuntas dari jumlah keseluruhan 33 siswa. Sementara 26 siswa lainnya tidak tuntas.

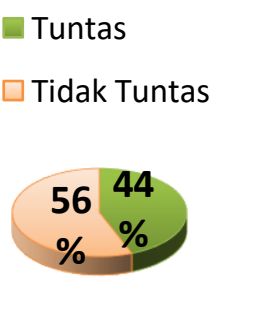


(a)

Gambar 4.2 Grafik Presentase Ketuntasan Hasil Belajar (a) Kelas Eksperimen (b) Kelas Kontrol

Siswa yang telah diberikan pembelajaran berbasis masalah dengan berpendekatan SSI pada materi minyak bumi memberikan pengaruh pada tercapainya ketuntasan hasil belajar terbaik pada indikator upaya menanggulangi dampak pembakaran bahan bakar fosil. Terdapat juga ketuntasan belajar paling jelek pada indikator menganalisis pembagian fraksi minyak bumi berdasarkan perbedaan titik didih. Siswa akan lebih memahami materi pembelajaran jika dapat menemukan permasalahan yang mereka temukan di lingkungan sekitar dan dapat menyelesaikannya daripada hanya memahami materi dengan cara menghafalkan. (Djonomiarjo, 2020) dalam penelitiannya menyatakan bahwa bahwa pembelajaran berbasis masalah efektif untuk meningkatkan hasil belajar siswa. Pembelajaran berbasis masalah dapat melatih untuk berfikir secara mandiri, kerja sama, dan dapat memunculkan sikap tanggung jawab siswa. Pembelajaran berbasis masalah dapat membuka pemikiran siswa untuk menemukan masalah dan memberikan solusi yang tepat dari permasalahan yang ditemukan. Senada dengan penelitian Janah \& Widodo (2018) pembelajaran berbasis masalah efektif dalam meningkatkan prestasi belajar siswa dengan alasan bahwa pembelajaran berbasis masalah tidak hanya membuat siswa berpikir aktif dan kreatif melainkan pembelajaran berbasis masalah menghadapkan siswa pada situasi yang menyenangkan untuk menyelesaikan permasalahan di kehidupan sehari-hari.

Aktivitas penyelesaian masalah melatih siswa untuk berpikir secara mandiri. Hal ini menyebabkan siswa akan lebih mudah mengingat dan memahami materi pelajaran. Selain itu, siswa juga akan termotivasi untuk berkeinginan menyelesaikan suatu masalah. Siswa bebas bereksplorasi dan mengkaji berbagai literatur berupa buku maupun internet, sehingga pembelajaran lebih efektif dan bermakna. Temuan bahwa pembelajaran berbasis masalah dapat meningkatkan hasil belajar siswa dapat dilihat pada Gambar 4.3 bahwa kelas eksperimen memiliki peningkatan hasil belajar yang lebih baik daripada kelas 
kontrol.

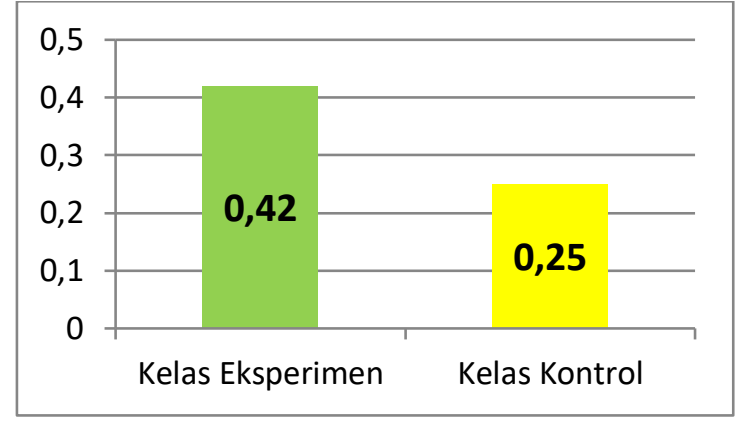

Gambar 4.3 Grafik N-Gain Hasil Belajar

Pada pengukuran sikap peduli lingkungan siswa digunakan angket yang terdiri dari 32 item pernyataan. Pengukuran lembar observasi menggunakan skala Likert yang memiliki lima pilihan sikap $($ sangat tidak setuju $=$ skor 1 , tidak setuju $=$ skor 2 , ragu-ragu $=3$, setuju $=$ skor 4 , dan sangat setuju $=$ skor 5). Berdasarkan perhitungan hasil akhir sikap peduli lingkungan siswa, kelas eksperimen memiliki rata-rata sikap peduli lingkungan lebih besar daripada kelas kontrol yang memiliki rata-rata sikap peduli lingkungan lebih rendah. Sedangkan rata-rata sikap peduli lingkungan siswa antara kelas eksperimen dengan kelas kontrol memiliki perbedaan yang dapat dilihat pada Gambar 4.4

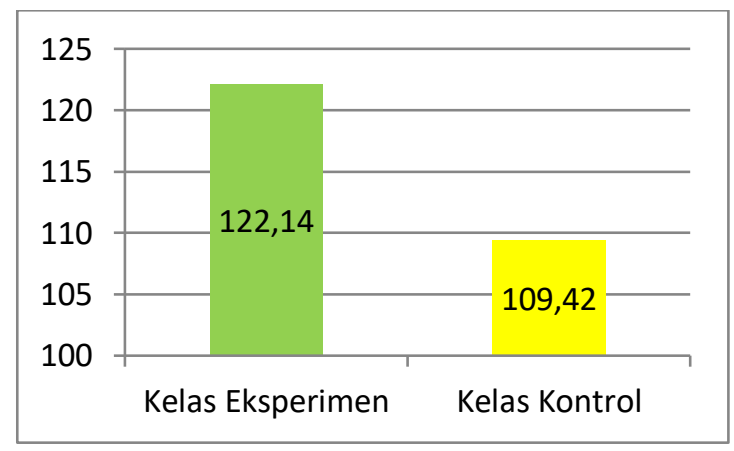

Gambar 4.4 Grafik Besaran Sikap Peduli lingkungan

Sikap peduli lingkungan kelas kontrol dan kelas eksperimen sama-sama mengalami kenaikan, akan tetapi kelas eksperimen memiliki peningkatan yang lebih tinggi daripada kelas kontrol. Pembelajaran berbasis masalah berpendekatan SSI yang dilakukan di kelas eksperimen berdampak pada meningkatnya sikap peduli lingkungan siswa. Materi yang didapatkan dalam pembelajaran selaran dengan permasalahan lingkungan yang ada di lingkungan sekitar. Siswa akan lebih berhati-hati dalam memanfaatkan dan menjaga sumber daya alam. Sedangkan pembelajaran dengan model konvensional pada kelas kontrol belum memberikan dampak peningkatan sikap peduli lingkungan siswa yang 
signifikan. Pada Gambar 4.5 dapat dilihat bahwa peningkatan sikap peduli lingkungan siswa kelas eksperimen lebih baik daripada kelas kontrol.

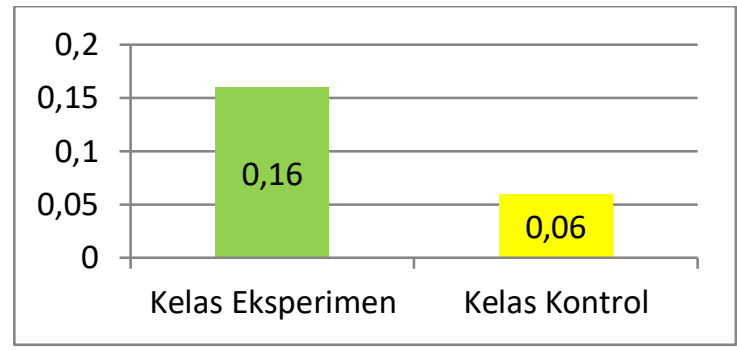

Gambar 4.5 Grafik N-Gain Sikap Peduli Lingkungan

Siswa mengingat materi pelajaran yang telah mereka pelajari melalui penemuan masalah di lingkungan sekitar dan kemudian menyelesaikan masalah yang dapat diaplikasikan pada kegiatan sehari-hari. Siswa dapat memiliki sikap negatif terhadap pembelajaran kimia disebabkan oleh faktor-faktor sebagai berikut: penggunaan metode pembelajaran, sikap guru terhadap siswa, pola asuh orang tua terhadap siswa, gaya belajar siswa, usia, gender, ketertarikan pada pembelajaran (Khan \& Ali, 2012).

Pada pengujian korelasi variabel antara hasil belajar dengan sikap peduli lingkungan menunjukkan hasil yang positif. Adanya korelasi positif antara hasil belajar dengan sikap peduli lingkungan ditunjukkan dengan nilai $r^{2}=(0,617) 2=0,3807$ dengan kontribusi sebesar 38,07\% terhadap sikap peduli lingkungan sedangkan faktor lainnya memiliki kontribusi sebesar $61,93 \%$. Sehingga dapat ditarik kesimpulan bahwa semakin tinggi nilai hasil belajar kimia pada materi minyak bumi semakin tinggi pula sikap peduli lingkungan siswa.

Korelasi yang positif antara hasil belajar dengan sikap peduli lingkungan dinyatakan kuat dibuktikan dengan nilai $r^{2}=0,617$. Hal ini perlu dipertahankan bagi guru supaya selalu menanamkan karakter peduli terhadap lingkungan. Guru diharuskan berupaya untuk memberikan materi pelajaran yang lebih aplikatif dan sesuai dengan isu permasalahan lingkungan sekitar. Sebagaimana dijelaskan oleh Sukmadinata (2003) besar kecilnya hasil belajar siswa dapat dinilai dari sikap, baik sikap penguasaan materi pembelajaran, kemampuan berpikir sains maupun kemampuan motorik siswa.

Berdasarkan respon siswa setelah pembelajaran berbasis masalah dan berpendekatan SSI, siswa memiliki respon positif terhadap permasalahan lingkungan di Kabupaten Rembang. Siswa mulai merasa prihatin dengan keadaan udara di lingkungan Kabupaten Rembang. Sebagai upaya penanggulangan pencemaran udara, siswa 
berkeinginan untuk menggunakan bahan bakar yang bermutu tinggi dan mengurangi penggunaan bahan bakar minyak yang berlebihan. Selain itu, siswa juga tertarik untuk melakukan sosialisasi kepada masyarakat disekitarnya tentang bahaya pembakaran minyak bumi yang berlebihan.

Selain jawaban tersebut, siswa juga memberikan respon terkait rencana tindak lanjut usai pembelajaran dengan model pembelajaran berbasis masalah berpendekatan SSI. Siswa memiliki jawaban yang bervariasi terkait hal ini, seperti keinginan untuk mengeksplor sumber daya alam sebagai sumber energi yang ramah lingkungan, menggunakan bahan bakar secara hemat, mengurangi penggunaan plastik, memilih bahan yang ramah lingkungan. Mengurangi penggunaan bahan bakar minyak dapat meminimalisir percemaran lingkungan yang terjadi. Edukasi tentang bahaya pembakaran minyak bumi dapat menumbuhkan pola pikir dan sikap yang positif bagi siswa untuk tidak berlebihan memanfaatkan minyak bumi.

\section{KESIMPULAN}

Simpulan dari penelitian ini adalah penerapan model pembelajaran berbasis masalah berpendekatan SSI pada materi minyak bumi efektif digunakan dalam pembelajaran untuk meningkatkan hasil belajar dan sikap peduli lingkungan siswa pada materi minyak bumi di MAN 2 Rembang.

\section{REFERENSI}

Agustina, R. P., Ashadi, \& Mulyani, B. (2017). Penerapan Model Pembelajaran Problem Based Learning (PBL) untuk Meningkatkan Sikap Ilmiah dan Prestasi Belajar Siswa pada Materi Sistem Koloid Kelas XI MIA SMA Negeri I Sukoharjo. Jurnal Pendidikan Kimia. 6 (2): 144-153.

Callahan, B. E. (2009). Enhancing Nature of Science Understanding, Reflective Judgment, and Argumentation Through Socioscientific Issues. Disertasi tidak dipublikasikan. Florida: University of South Florida

Djonomiarjo, T. (2020). Pengaruh Model Problem Based Learning terhadap Hasil Belajar. Aksara: Jurnal Ilmu Pendidikan Nonformal. 5 (1): 39.

Janah, M. C., \& Widodo, A. T. (2018). Pengaruh Model Problem Based Learning terhadap Hasil Belajar dan Keterampilan Proses Sains. Jurnal Inovasi Pendidikan Kimia. 12 (1): 20972107.

Khan, G. N., \& Ali, A. (2012). Higher Secondary School Students' Attitude towards Chemistry. Asian Social Science. 8 (6): 165-169. 
Lestari, Y. (2018). Penanaman Nilai Peduli Lingkungan dalam Pembelajaran Ilmu Pengetahuan Alam. Trihayu: Jurnal Pendidikan Ke-SD-an. 4 (2): 332-337.

Purwanti, D. (2017). Pendidikan Karakter Peduli Lingkungan dan Implementasinya. DWIJA CENDEKIA: Jurnal Riset Pedagogik. 1 (2): 14-20.

Sofiana, S., \& Wibowo, T. (2019). Pengembangan Modul Kimia Socio-Scientific Issues ( SSI ) Materi Reaksi Reduksi Oksidasi 1 Madrasah Al-Irsyad Gajah Demak 2 Pendidikan Kimia Universitas Islam Negeri Walisongo Semarang. Journal of Education Chemistry. 1 (2): 92106.

Subandi, E., Joharmawan, R., \& Santoso, A. (2017). Pengaruh Penggunaan Model Pembelajaran Problem Based Learning (PBL)-Study History Sheet (SHS) Bahan Ajar Berbasis Green Chemistry pada Materi Kelarutan dan Hasil Kali Kelarutan terhadap Prestasi Belajar Siswa Kelas XI SMA Negeri 10 Malang. J-PEK (Jurnal Pembelajaran Kimia). 2 (2): 41-49.

Sugiyono. (2012). Metode Penelitian Kualitatif, Kuantitatif, dan $R \&$ D. Bandung: Alfabeta

Sukmadinata, N. S. (2003). Landasan Psikologi Proses Pendidikan. Bandung: PT. Remaja Rosdakarya

Sulaeha, S., Danial, M., \& Wijaya, M. (2016). Pengaruh Model Pembelajaran Berbasis Masalah (Problem Based Learning) terhadap Hasil Belajar Siswa Kelas X SMA Negeri 1 Tamalatea Kabupaten Jeneponto (Studi pada Materi Pokok Reaksi Reduksi Oksidasi). Chemica. 17 (2): 94-102.

Susanti, S., Masriani, \& Hadi, L. (2017). Pengaruh Model Problem Based Learning Terhadap Sikap Peduli Lingkungan Siswa SMP Negeri 6 Pontianak. Jurnal Pendidikan Dan Pembelajaran Khatulistiwa. 6 (11): 56-67.

Tal, T., Kali, Y., Magid, S., \& Madhok, J. J. (2011). Socio-Scientific Issies in the Classroom: Teaching, Learning and Results. 39 (10).

Zeidler, D. L., Sadler, T. D., Simmons, M. L., \& Howes, E. V. (2005). Beyond STS: A Researchbased Framework for Socioscientific Issues Education. Science Education, Netherlands: Senses Publisher. 89 (3): 343-367.

Zuchdi, D., Ghufron, A., Syamsi, K., \& Masruri, S. (2014). Pemetaan Implementasi Pendidikan Karakter di SD, SMP, dan SMA di Kota Yogyakarta. Jurnal Pendidikan Karakter. 4 (1): $153-162$. 